International Journal of Social Sciences and Humanities
Available online at www.sciencescholar.us
Vol. 5 No. 1, April 2021, pages: 45-56
e-ISSN: 2550-7001, p-ISSN: 2550-701X
https://doi.org/10.29332/ijssh.v5n1.827

\title{
Illegal Sand Mining and Sar Local Wisdom: A Case Study in Merauke
}

\author{
D corssark \\ Trinovianto George Reinhard Hallatu a, Darsono Wisadirana ${ }^{b}$, Sholih Mu'adi c , Anif Fatma Chawa d \\ Manuscript submitted: 27 January 2021, Manuscript revised: 18 February 2021, Accepted for publication: 09 March 2021

\section{Corresponding Author ${ }^{\text {a }}$}

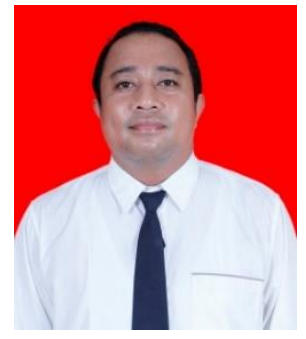

\section{Keywords} \\ environmental problems; \\ illegal sand mining;

\section{Abstract} \\ Illegal sand mining is carried out causing bad environmental problems. There \\ needs to be a solution to solve the problem of illegal sand mining. The purpose \\ of this study is to describe the impact of illegal sand mining in Merauke and the \\ role of local wisdom to prevent illegal mining. This research is descriptive \\ qualitative research. The place of research is Ndalir beach, the beach where \\ sand mining occurs, and also Tomer village as one of the villages affected by \\ illegal sand mining. Data was collected by direct observation and also in-depth \\ interviews with several communities. The data obtained is that illegal sand \\ mining provides benefits to the customary landowners of the sand village and \\ also provides income to the sand miners. The negative impact of illegal mining \\ is that it causes damage to mangrove forests resulting in abrasion, rising \\ seawater to roads and homes, damage to roads and bridges. The solution is to \\ adopt the local wisdom of the Kanum tribe, to prevent illegal sand mining.
}

Merauke;

sar local wisdom;

International Journal of Social Sciences and Humanities (C) 2021.

This is an open access article under the CC BY-NC-ND license (https://creativecommons.org/licenses/by-nc-nd/4.0/).

\section{Contents}

Abstract

1 Introduction

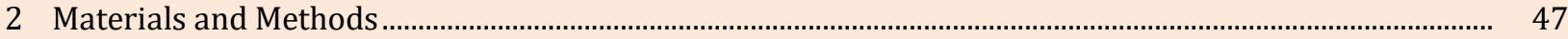

3 Results and Discussions ................................................................................................................................. 48

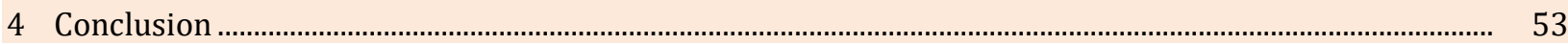

\footnotetext{
a Department of Doctoral of Sociology, Brawijaya University, Malang, Indonesia and Department of Primary Teacher Education, Musamus University, Merauke, Indonesia

b Department of Doctoral of Sociology, Brawijaya University, Malang, Indonesia

c Department of Doctoral of Sociology, Brawijaya University, Malang, Indonesia

${ }^{\mathrm{d}}$ Department of Doctoral of Sociology, Brawijaya University, Malang, Indonesia
} 


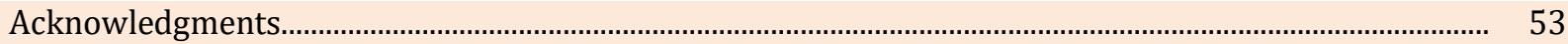

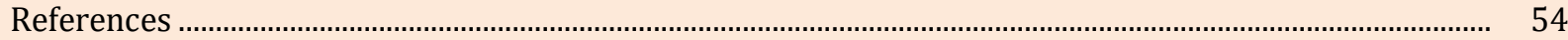

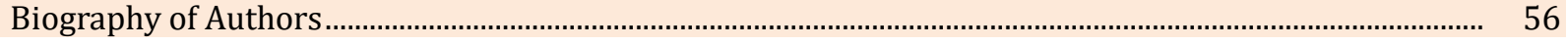

\section{Introduction}

Today, the environmental problem is a global problem that is being discussed everywhere. Many human activities cause these environmental problems, like opening the land of agricultural or housing which requires to cut down the trees or forest. There is also sand mining carried out intending to take the sand as the material of the building. The sand taken can come from beaches or dredged mountains.

Illegal sand mining also occurs in Merauke (Batbual, 2014;2018). Merauke is located south of Papua island, causing Merauke is around by beaches. The illegal sand mining was done by taking the beach sand. This illegal sand mining has occurred since 1990 and caused damage to the environment, it was the damage of mangrove forest and abrasion in the beach area (Masiyah, 2011; Pornpimon et al., 2014; Widodo, 2012). Sand mining has been regulated under the rule of the government of Merauke No. 14/2011 concerning Management of Non-Metallic Mineral and Rock Mining Business. However, in the reality, the sand miners ignored the local regulation. As the result, environmental damage is getting worse. One of the worst environmental damage is the cut-off access from Merauke to Naukenjerai district. Also, one of the concerns caused by illegal mining is the entry of seawater into Dogamit Lake and Rawa Biru Lake, the clean water resources in Merauke (Batbual, 2014).

Talking about the prohibition to take or explore the natural resources in excess, there is the local wisdom of Kanum tribe that regulates it. The local wisdom namely sar. Principally, the implementation of local wisdom is to prohibit the human to take or explore natural resources from the place that is applied sar and within a minimum period of 1000 days (Palittin \& Hallatu, 2019). If there is a violation, then that person will be subject to traditional sanctions. In connection with the occurrence of illegal sand mining, prevention can be done by adopting local wisdom sar. the existence of customary sanctions contained will make people afraid to violate the ban (Rim-Rukeh et al., 2013). Indirectly, the sand mining will be controlled and it reduces the environmental damage was occur.

In this article, we will discuss the impact of illegal sand mining that occurred in Naukenjerai District, Merauke Regency, Papua, Indonesia, especially the impact on the environment. Besides that, in this article, we will discuss the solution which adopted sar local wisdom, the local wisdom from Kanum tribe, to reduce and prohibit illegal sand mining activities. The mining activity is one of the activities to explore the natural resources to full the needed of human life (Koehnken, 2018; Hartanto \& Suyoto, 2017). One of the natural resources being explored is sand. Sand mining is the activity of removing the sand from nature (Ashraf et al., 2011). According to the report of UNEP in 2014, there much 32 to 50 billion tons of sand and gravel are extracted globally every year (Koehnken, 2018; Atahau et al., 2020; Patriadi et al., 2015). Sand and gravel are used for infrastructure development, there are buildings, roads, and land reclamation. In Indonesia, sand is a group $\mathrm{C}$ mining material, that is the material not affect human life indirectly.

Sand mining is mostly occurring in the developing country and city, like China, India, and Vietnam (Elavenil et al., 2017), Malaysia (Ashraf et al., 2011), Bangladesh (Khan \& Sugie, 2015), Iceland (Musah, 2009), South Africa (Gondo et al., 2009), and also Indonesia (Widiastuti \& Mote, 2018; Syah \& Hartuti, 2018; Supriharyono, 2004). Even sand mining has occurred since the Romania era (Koehnken, 2018). It is because sand is needed for the development itself. Availability of sand is in large quantities on earth, it makes sand mining activities increasingly widespread. The sand miners are no longer pay attention to the rule of sand mining. This activity has a positive and negative impact. The positive impact is in the economy and social fields, while the negative impact was environmental and nature damage (Ashraf et al., 2011). The positive impact of sand mining was increased infrastructure development, the opening up jobs for miners workers, and increase income for the landowners (Musah, 2009). The review from Gavriletea also revealed the positive impact of sand mining, namely the changes in water pattern, increased the land landscape, increased the soil moisture, and also appear the new water resources (Gavriletea, 2017; Vitasurya, 2016; Rohayu \& Absori, 2019). 
Besides the positive impact, sand mining has a more negative impact on the environment and nature. the most pronounced impact is erosion and sedimentation around the sand mining site so that it disrupts the stability of the soil/sand structure in the place (Ashraf et al., 2011; Gavriletea, 2017; Khan \& Sugie, 2015; Elavenil et al., 2017; Musah, 2009; Dung \& Le, 2018; Syah \& Hartuti, 2018; Supriharyono, 2004). Sand mining also causes decreases the agricultural land and plantations, thereby reducing sources of income for farmers (Musah, 2009; Syah \& Hartuti, 2018). The result of sand mining is the disruption of the ecosystem and the amount of flora and fauna around the sand mining site (Ashraf et al., 2011; Gavriletea, 2017; Musah, 2009; Syah \& Hartuti, 2018). Sand mining activities create large craters or holes and these holes can become a breeding ground for mosquitoes or other animals that have the potential to spread disease (Syah \& Hartuti, 2018). The other negative impacts arising from sand to spread disease (Khan \& Sugie, 2015), the commotion caused by sand dredging by heavy equipment (Dung \& Le, 2018), damage of road (Elavenil, 2017), and reduced the amount of fish caught by a fisherman (Supriharyono, 2004).

The environmental damage today, can be repaired and prevented by applying local wisdom. Local wisdom is the indigenous science that is derived from their ancestors and is related to nature (Phongphit, 2002). If the local wisdom is applied, the indigenous people must obey it. It because local wisdom practices contain rules that are considered taboo and have traditional sanctions for those who break them. Because of that, the indigenous people will take good care of nature and the environment and also use the natural resources regularly (Rim-Rukeh et al., 2013). Indirectly, the local wisdom can be as the guide of environment and nature from the damage by a human (Hasbiah, 2015).

In Indonesia, each region has its local wisdom. It is applied to protect nature and the environment, and also ensure its sustainability. In Sumatra, there is local wisdom that regulates fish conservation, namely ngalau agung (Hendrik, 2007). There is tuk serco, the local wisdom from Kendal, to maintain the conservation of water resources (Siswadi et al., 2011; Maya et al., 2020). In Kalimantan, there is some local wisdom. There is local wisdom that serves to maintain the management of water resources through Bukit Kelam National Park (Antonius et al., 2018), the application of sacral forest by Dayak Kenyah tribe (Anau, 2019), and sacral forest to protect of forest in Ruteng Mountain by Manggarai tribe (Iswandono et al., 2015). In Maluku and Papua, sasi local wisdom is the local wisdom to protect the natural resources from forest and sea (Suntoko et al., 2016; Boli et al., 2014; Silaya \& Siahaya, 2018).

Kanum tribe, one of the indigenous tribe in Merauke, is the tribe that depends on their life to nature. Because of that, their ancestors inherited the local wisdom that must be obeyed by Kanum tribe, to preserves their nature and environment. One of them is sar. Principally, sar local wisdom is forbidden human to take and explore the natural products from the place which is applied by sar within a certain period. This local wisdom usually held if there is someone who died, especially for the man of Kanum tribe, intending to respect that people (Hallatu et al., 2020).

The implementation of the sar was preceded by a traditional ceremony namely yamu ceremony, that attended by customary leaders, customary elders, grieving families, and also all members of the Kanum tribe. Areas that are applied sar will be given a misar sign, which is a sign in the form of coconut leaves tied to wood and embedded in the area to be applied sar. The aim is that the communities or foreigners know that the place must not be entered or even taken of its natural products. If there is a violation, then that person will be subject to customary sanctions. When the sar time is over, a traditional ceremony will be held again, which will also be attended by the customary leaders, customary elders, grieving families, and also native Kanum tribes. When the sar sign is revoked, this means the area has been allowed to be taken and processed natural products.

\section{Materials and Methods}

This research is a descriptive qualitative research. The purpose of this study is to describe the impact caused by sand mining in Merauke and also the role of sar as a way to reduce sand mining activities. The approach used in this research is the ethno-science approach, which is the study of scientific knowledge through culture that is related to nature and develops in society can be seen in Figure 1.

Hallatu, T. G. R., Wisadirana, D., Mu'adi, S., \& Chawa, A. F. (2021). Illegal sand mining and sar local wisdom: a case study in Merauke. International Journal of Social Sciences and Humanities, 5(1), 45-56.

https://doi.org/10.29332/ijssh.v5n1.827 


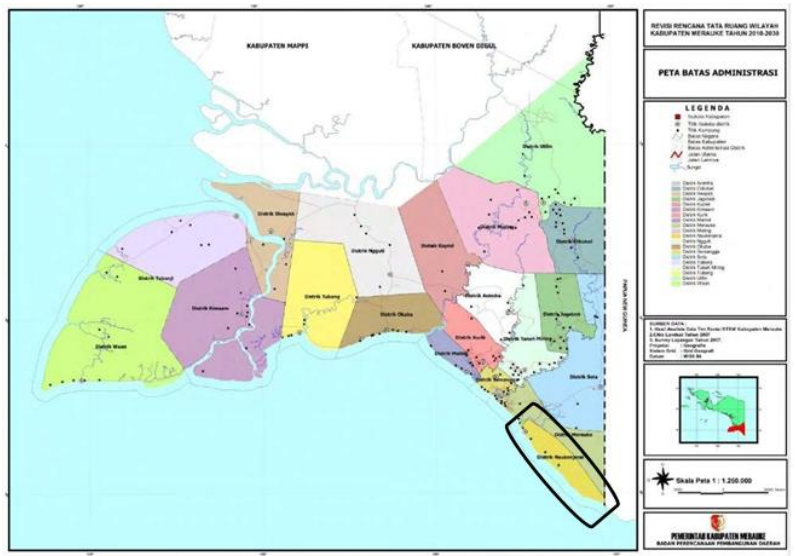

Figure 1. Map of Naukenjerai District, the place of Ndalir and Tomer beach

The study was conducted in the Ndalir beach area and Tomer beach area. Ndalir beach is one of the places where sand mining occurs. Tomer Beach is one of the beaches affected by sand mining activities in Ndalir and also the residence of the Kanum tribe itself. Data retrieval is done by direct observation, interviews, and literature study. Direct observations were made at the sand mining site, which is on the beach around the Naukenjerai district to see the condition of the sand mining and the impact on the environment. Observations were also made in the Tomer beach area as one of the beaches affected by sand mining activities in Ndalir. Interviews were conducted with the Ndalir and Tomer communities regarding the impacts they felt as a result of sand mining. Specifically for the Tomer community, interviews were also conducted related to local wisdom sar. The literature study was conducted to obtain data related to sand mining. The data obtained were analyzed using descriptive techniques. Stages of data analysis performed are data reduction, data presentation, data verification, and concluding.

\section{Results and Discussions}

Merauke Regency, one of the districts currently under development. The location of Merauke is directly adjacent to the Arafura Sea which means that almost all of Merauke's territory is close to the sea. This makes Merauke rich in marine products and also beach sand which is used as mining material (Widiastuti \& Mote, 2018). This abundant amount of beach sand causes many legal and illegal mining activities. Sand mining is carried out to support infrastructure development in Merauke along with developments in Merauke itself.

Sand mining activities in Merauke have occurred since the 1990s. Several points become sand mining sites, including the beach areas of Urumb, Wendu, and Matara as well as the Ndalir, Nasem, and Buti beach areas (Batbual, 2014;2018). Urumb, Wendu and Matara beach areas are areas located in the Semangga district. The Ndalir and Nasem beach areas are in the Naukenjerai district, while the Buti beach is in the Samkakai district. Considering that Merauke is one of the developing regencies, there is development around the Merauke area. This causes the demand for sand to increase. The type of sand in Merauke is included in the category of sand which is suitable as a construction material (Djamali et al., 2016). For this reason, illegal sand mining activities are increasingly happening. The sand sellers who are the customary rights owners of the area/location of the illegal sand mining and are the indigenous people of Merauke admit that one of the reasons for selling sand is due to economic demands (Widiasturi \& Mote, 2018). The absence of regular income is because they work as farmers and fishermen, while their daily needs are increasing and other needs such as children's education are the reason they sell sand. This was also expressed by a native of the Kanum tribe who lives in the Naukenjerai district. He admitted that he was sold sand for his children's school needs, but he does that just once.

Apart from economic demands, illegal sand mining activities occur due to the ineffectiveness of the existing regulations on the prohibition of illegal sand mining. The absence of a control function from the government or agencies related to sand mining is the cause of the ongoing illegal sand mining activity. Even the indigenous people, the sand sellers, said that they were not aware of any regulations governing sand 
extraction. They also admit that there has never been any socialization from the government or related agencies to inform them of the prohibition or impact of the illegal sand mining activity. Even though in reality, they know the impact of illegal sand mining activities on their environment, they still sell sand because of this economic demand.

\section{Impact of Sand Mining in Merauke}

The sand mining process begins with the sale of sand by people who feel they have traditional rights to the sand village in the area. According to interviews, they sell the sand to buyers for IDR 300,000 to IDR 500,000 for once transport. During a day, approximately five trucks came to mine the sand. The community sells the sand on the grounds to fulfill their daily needs. These sand mining activities make it easier for them to earn money. Profits are also obtained by sand digging laborers. These workers are paid IDR 100,000 for each sand excavation.

Illegal sand mining in the Naukenjerai district takes place around Ndalir beach and also in Kuler village, one of the villages in the Naukenjerai district. Although it gives benefits to the customary landowners of the sand village and also the laborers, sand mining has a negative impact on the environment around the mine. As a result of illegal sand mining in Kuler village, there were large puddles with a diameter of approximately 3-4 meters and a depth of approximately 2 meters. These puddles become water reservoirs and also breeding grounds for animals such as mosquitoes during the rainy season. These puddles also caused many trees to fall, due to tree roots that could not stand upright because the sand/soil around the tree had been taken.

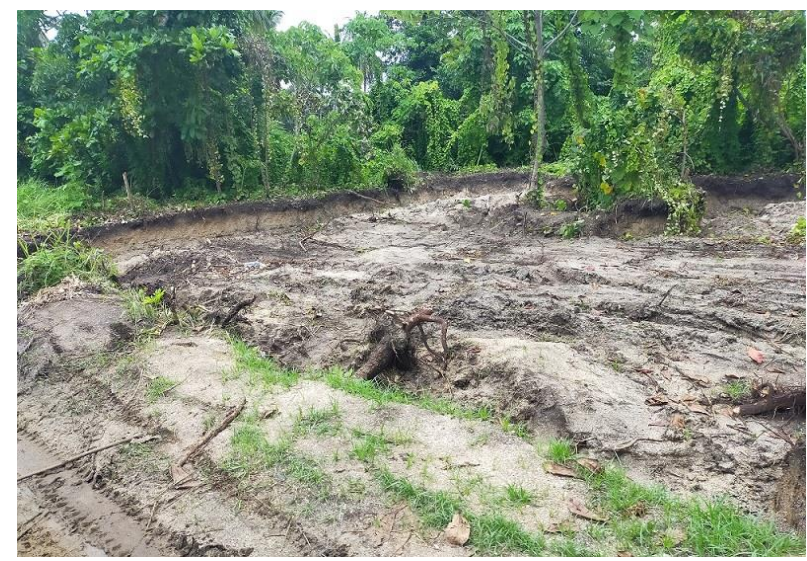

Figure 2. One of the puddles in Kuler district caused by illegal sand mining activities (personal documentation)

Illegal sand mining activities have also caused abrasion around the beaches in Naukenjerai district, starting from Ndalir beach, Kuler beach, Onggaya beach, and also Tomer beach. The beach areas of Ndalir have experienced severe abrasion. This abrasion has resulted in the destruction of mangrove forests around the beach. Abrasion around the beach of Ndalir causes the advancement of the coastline so that even the seawater damages residents' homes. As a result of damage to people's homes, they eventually moved their villages to safer areas (still in the Ndalir beach area).

Hallatu, T. G. R., Wisadirana, D., Mu'adi, S., \& Chawa, A. F. (2021). Illegal sand mining and sar local wisdom: a case study in Merauke. International Journal of Social Sciences and Humanities, 5(1), 45-56. 


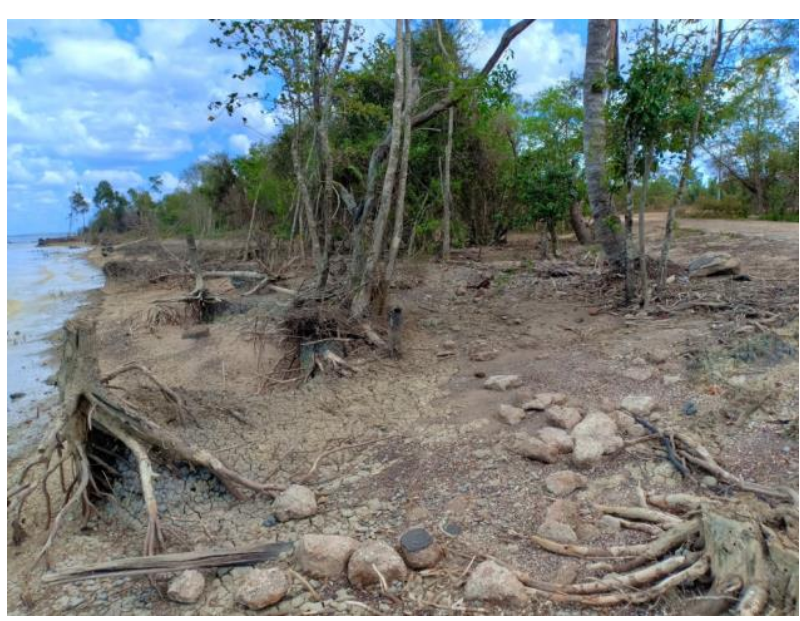

Figure 3. The old Ndalir village area that was damaged by abrasion (personal documentation)

This abrasion has resulted in the destruction of mangrove forests around the beach. Since abrasion has occurred, communities around the Ndalir beach have made simple embankments made of piles of sacks filled with sand and arranged along the Ndalir beach. This embankment is made to block water that rises to communities' houses or roadways when high tide occurs. But over time and also the cessation of sand mining that occurred, the dike did not function so that the water continued to reach communities' houses and road bodies. The situation becomes worse when there is rain accompanied by strong winds.



Figure 4. The area of Ndalir beach provided artificial levees by local communities (personal documentation)

Damage to mangrove forests due to abrasion around the beach of Ndalir, sometimes there is a tidal flood which is the rise of water up to the road and communities' houses when the tide. Rising water to the body of this road makes the roads and bridges damaged. As a result, access to other villages is hampered. If the weather is bad, that is rain accompanied by strong winds, the bridge cannot be crossed, so the access road becomes broken. The Ndalir Bridge is a link between the Merauke district and the villages in the Naukenjerai district. 


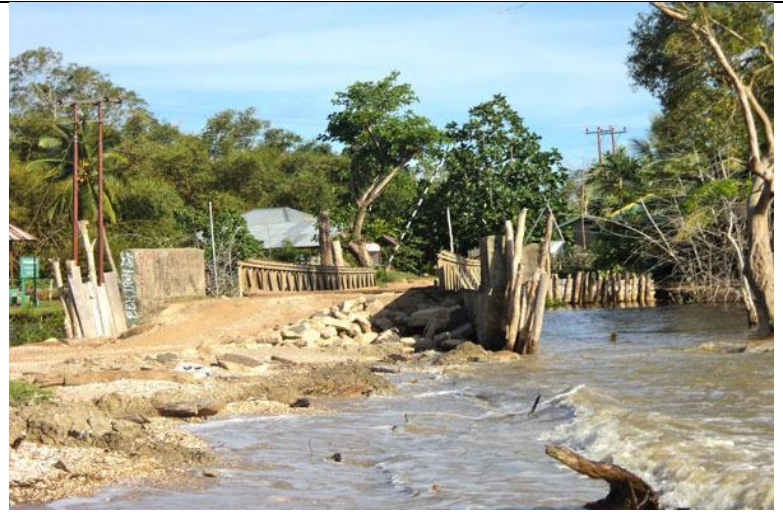

Figure 5. Tidal floods that have risen to the body of the road around the Ndalir beach (Batbual, 2014)



Figure 6. Ndalir Bridge damaged by high tide (personal documentation)

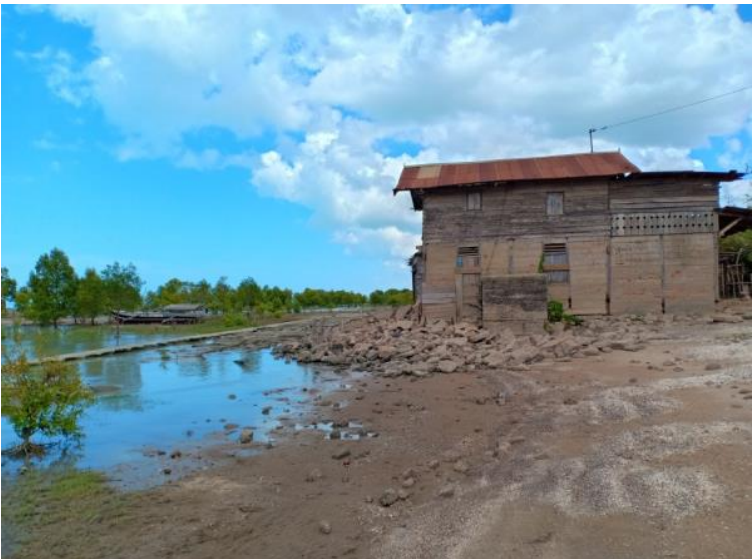

Figure 7. Communities' homes are located on the edge of Ndalir beach which was hit by the tide (personal documentation)

Hallatu, T. G. R., Wisadirana, D., Mu'adi, S., \& Chawa, A. F. (2021). Illegal sand mining and sar local wisdom: a case study in Merauke. International Journal of Social Sciences and Humanities, 5(1), 45-56. https://doi.org/10.29332/ijssh.v5n1.827 
Abrasion due to sand mining does not only occur at Ndalir beach. Tomer Beach, which is a channel from Ndalir beach, is also affected. Although the distance from Ndalir beach to Tomer is about $14 \mathrm{~km}$, Tomer beach is also still affected by abrasion itself. Based on interviews with Tomer villagers, since abrasion has occurred, seawater at high tide can reach the coastline and village boundaries. Even if there are high waves accompanied by strong winds, seawater reaches the village. The distance between the shoreline and Tomer village itself is about $1 \mathrm{~km}$. mangrove forests located on the beach of Tomer were damaged by abrasion that occurred.

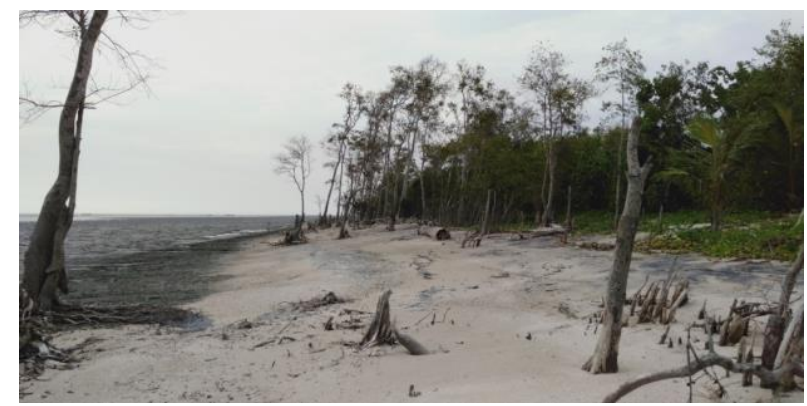

Figure 8. Tomer beach area affected by abrasion due to sand mining in Ndalir (personal documentation)

In addition to abrasion, the resulting impact is a reduction in the income of Ndalir and Tomer communities in the field of catching marine products such as fish and shrimp. The location of Ndalir and Tomer, which is directly adjacent to the Arafura sea, makes these two villages rich in marine products. For this reason, most Ndalir and Tomer communities work as fishermen, with seafood such as milkfish, shrimp, and shellfish. As a result of abrasion that occurs, the amount of their catch is reduced and has an impact on their income. The shellfish itself is used by communities as a basic ingredient of lime, a complement of areca nut.

The long-term negative impact resulting from this sand mining activity is the entry of saltwater into clean water sources in Merauke. Rawa Biru village is a village that is a source of clean water for Merauke regency. The location of this village is directly adjacent to Tomer village. Therefore, if sand mining continues, sea water may reach Rawa Biru. This means threatening the existence of clean water sources.

\section{Solution to Prohibition of Sand Mining in Merauke}

Solutions to solve the problem of sand mining in Merauke, have been given a lot. Regulations from the government regarding sand mining have been issued. However, due to the absence of direct supervision from the government or department related to sand mining and also strict action for those who were caught, sand mining continues to this day. The Government of Merauke itself has issued a Regulation of the Regent of Merauke Regency No. 14/2011 concerning Management of Non-Metallic Mineral and Rock Mining Business. However, this regulation alone, does not regulate how much sand can be taken for infrastructure development purposes. Therefore, sand mining still occurs.

Sand which is group C mining material, the management is directly under the Department of Mining and Energy. As for Papua itself, this department is still in Jayapura, the capital of Papua. This also results in the absence of supervision from related agencies for sand mining activities. The Civil Service Police Unit did not dare to arrest the sand miners, because there were no rules that allowed them to arrest the sand laborers. All of that is under the supervision of the Department of Mining and Energy. The lack of supervision from related agencies and the courage of the civil service police unit to arrest illegal mining actors, has caused this activity to occur even more in numbers.

The problem of illegal mining can adopt the culture or local wisdom of the Kanum tribe which is related to the environment. Indigenous people living in Merauke, especially in Ndalir and Tomer, still uphold their culture compared to the regulations made by the government. For them, culture is advice from their ancestors that must be implemented. If not implemented, there will be traditional sanctions that will punish them. Especially culture related to the environment and nature. These cultural practices contain traditional beliefs that are considered taboo for the community so that they refrain from using natural resources irregularly (Ram-Rukeh et al., 2013). 
Sar culture is a culture whose implementation prohibits humans from taking or processing natural products from an area that is being applied sar for a certain period. If there is a violation of this culture, then the relevant person will be subject to customary sanctions. The role of tradition is very strong in this local wisdom, making native Kanum people and also people who know about sar not dare to break it.

Prohibition that exists in this local wisdom can be a solution to the problem of sand mining. If the beach area which is usually used as a place for mining sand enforced the rules that contain sar culture, then the local communities, the customary rights of the village, and also the sand miners, will not dare to mine sand from the place. The existence of customary sanctions that are applied in local wisdom is something that is and is feared so that no one dares to violate it. However, in its application, it must be preceded by socialization from traditional leaders and also the government to the Kanum indigenous people in the Naukenjerai district and also to the people outside the Naukenjerai district, especially the liar sand miners. This is so that all parties see the prohibition so that it can be obeyed by all groups.

Enforcement of sar also will indirectly improve the state of nature that has been damaged. The absence of sand taken again will make the land landscape flat again because the sand will automatically cover the holes that arise due to sand mining. Also, the mangrove forest will be fertile again so that it can function as a barrier to seawater. If the mangrove forest functions again, then abrasion will not occur. Thus, natural damage can be prevented due to sand mining.

\section{Conclusion}

Sand mining that occurred in Merauke, had a positive impact on several parties. The owners of the customary land rights of the hamlet can increase their income and earn large amounts of money in a short time. Sand mining also benefits sand miners. The negative impact of sand mining is causing natural damage around the coast of Ndalir to Tomer beach. The natural damage that occurred was the end of mangrove forests around the coast of Ndalir to Tomer, the occurrence of abrasion, rising seawater to the coastline, the road, to the communities' homes in case of high tide. The rising sea level has caused damage to roads and bridges, especially the Ndalir bridge which is a link between the city of Merauke and the Naukenjerai district. For the long term, if sand mining continues to occur, then seawater may arrive at Rawa Biru Village, a village that is a place for clean water sources for Merauke itself. The application of sar culture, the culture of the Kanum tribe, can be one solution to prevent sand mining. The strong role of customary in this culture has prevented communities from violating it. Sar culture can also improve the natural condition that has been damaged, namely improving the landscape of the land and also restores the condition of mangrove forests that have been damaged. That way, abrasion can be prevented and natural damage can be overcome. The application of sar culture as a solution to solving the problem of illegal sand mining in the Naukenjerai district needs to be reviewed or investigated more deeply. Customary leaders as well as government, as well as assisted by academics, can sit together to make a regulation on the prohibition of mining sand using the sar culture. with the use of sar culture, can indirectly introduce sar culture more widely and preserve its culture, and can also prevent illegal sand mining from occurring again, because of the existence of customary rules that have been stipulated in government regulation.

\section{Acknowledgments}

We are grateful to two anonymous reviewers for their valuable comments on the earlier version of this paper.

Hallatu, T. G. R., Wisadirana, D., Mu'adi, S., \& Chawa, A. F. (2021). Illegal sand mining and sar local wisdom: a case study in Merauke. International Journal of Social Sciences and Humanities, 5(1), 45-56. 


\section{References}

Anau, N., Hakim, A., Leksono, A.S., Setyowati, E. (2019). Local Wisdom of the Dayak Kenyah Customary Community in the Management of Tana Ulen in Kayan National Park, Mentarang, North Kalimantan. International Journal of Science and Research, 8(4), 1413-1418.

Antonius, Hakim, A., Leksono, A. S., \& Setyowati, E. (2018). Water Resources Management through Government Policy and Local Wisdom in Bukit Kelam Nature Tourist Park Sintang Regency West Kalimantan Indonesia. International Journal of Science and Research, 7(1), 645-651. https://doi.org/10.21275/ART20179254

Ashraf, M. A., Maah, M. J., Yusoff, I., \& Wajid, A. \& Mahmood, K. (2011). Sand Mining Effects, Causes And Concerns : A Case Study From Bestari Jaya, Selangor, Peninsular Malaysia. Scientific Research and Essays, 6(6), 1216-1231. https://doi.org/10.5897/SRE10.690

Atahau, A. D. R., Huruta, A. D., \& Lee, C. W. (2020). Rural microfinance sustainability: Does local wisdom $\begin{array}{llll}\text { driven-governance } \quad \text { work?. Journal of Cleaner } & \text { Production, 267, }\end{array}$ https://doi.org/10.1016/j.jclepro.2020.122153

Batbual, A. Penambangan Pasir Marak, Mangrove Hilang, Abrasi Pantai Merauke Mengkhawatirkan. [Internet], 2014 [cited 11 November 2019]. Available from http://www.mongabay.co.id/2014/04/29/penambanganpasir-marak-mangrove-hilang-abrasi-pantai-merauke-mengkhawatirkan.

Batbual, A. Tambang Pasir Menggila di Merauke, Warga Khawatir Bencana. [Internet]. 2018. [cited 11 November 2019]. Available from https://www.mongabay.co.id/2018/12/12/tambang-pasir-menggila-dimerauke-warga-khawatir-bencana/

Boli, P., Yulianda, F., Damar, A., Sudharma, D., \& Kinseng, R. (2014). Benefits of Sasi for Conservation of Marine Resources in Raja Ampat, Papua. Jurnal Manajemen Hutan Tropika Oournal of Tropical Forest Management), 20(2), 131-139. https://doi.org/10.7226/jtfm.20.2.131

Djamali, R. A., Betaubun, P., Hermanuadi, D., \& Syaban, R. A. (2016). Pemetaan Kognitif Penyebab dan Dampak Eksplotasi Pasir Sepanjang Sempadan Pantai di Kabupaten Merauke. Seminar Nasional Hasil Penelitian Dan Pengabdian Masyarakat 2016, 114-119.

Dung, N. M., \& Le, N. P. (2018). An Analysis of River Sand Mining Management in Cau River of Vietnam. Asian Journal of Research in Business Economics and Management, 5(1), 19-32. https://doi.org/10.5958/22497307.2015.00003

Elavenil, S., Livingston, J. \& Parameswari, K. (2017). Case Study On Illegal Sand Mining In Tamil Nadu: Alternate Solution By Replacing Natural Sand By M-Sand. International Journal of Mechanical and Production Engineering Research and Development, 7(6), 279-284.

Gavriletea, M. D. (2017). Environmental Impacts of Sand Exploitation . Analysis of Sand Market. Sustainability, 9, 1118: 1-26. https://doi.org/10.3390/su9071118

Gondo, T., Mathada, H., Amponsah-dacosta, F. (2019). Regulatory And Policy Implications of Sand Mining Along Shallow Waters Of Njelele River In South Africa. Jamba - Journal of Disaster Risk Studies, 11(3), 1-12.

Hallatu, T. G. R., Wisadirana, D., Muadi, S., \& Chawa, A. F. (2020). Manifest and Latent Function from Sar Local Wisdom of Kanum Tribe in Merauke. Opción: Revista de Ciencias Humanas y Sociales, 93, 315-330.

Hartono, D. A., \& Suyoto. (2017). Penanganan Kasus Penambangan Galian C Ilegal Di Kawasan Pegunungan Kendeng Selatan dan Pegunungan Kendeng Utara di Kabupaten Pati. Prosiding Seminar Nasional Publikasi Hasil-Hasil Penelitian dan Pengabdian Masyarakat, 107-122.

Hasbiah, A. (2015). Analysis of Local Wisdom As An Environmental Conservation Strategy In Indonesia. Sampurasus e-Journal, 1(1), 2-7.

Hendrik. (2007). Ikan Larangan Sebagai Bentuk Kearifan Lokal Dalam Pemanfaatan Sumberdaya Perairan Umum (Studi Kasus pada Beberapa Nagari di Sumatera Barat). Berkala Perikanan Terubuk, 35(1), 1-10.

Iswandono, E., Zuhud, E. A.M., Hikmat, A., \& Kosmaryandi, N. (2015). Integrating Local Culture into Forest Conservation: A Case Study of The Manggarai Tribe in Ruteng Mountains, Indonesia. Jurnal Manajemen Hutan Tropika (Journal of Tropical Forest Management), 21, 55-64. https://doi.org/10.7226/jtfm.21.2.55

Khan, S., \& Sugie, A. (2015). Sand Mining and Its Social Impacts on Local Society in Rural Bangladesh : A Case Study of a Village in Tangail District. Journal of Urban and Regional Studies on Contemporary India, 2(1), 111.

Koehnken, L. \& Rintoul, M. (2018). Impacts Of Sand Mining On Ecosystem Structure, Process \& Biodiversity In Rivers. WWF. 
Masiyah, S. (2011). Biodiversitas Mangrove Di Kabupaten Merauke Provinsi Papua Jurnal Ilmiah Agribisnis dan Perikanan (Agrikan UMMU-Ternate), 9(1): 1-7.

Maya, D. N. K. W., Suda, I. K., \& Subrata, I. W. (2020). Procurement of Goods and Services Based on Local Wisdom: an Implementation Study. International Journal of Social Sciences and Humanities, 4(1), 106-116.

Musah, J. A. \& Barkarson, B.H. (2009). Assessment Of Sociological And Ecological Impacts Of Sand And Gravel Mining - A Case Study Of East Gonja District ( Ghana ) And Gunnarsholt ( Iceland ), Final Project of Land Restoration Training Programme, 75-108.

Palittin, I. D. \& Hallatu, T. G. R. (2019). Sar: Kanume Tribal Culture In Environmental Conservation To Reduce Global Warming Effects. Proceedings IOP Conf. Series: Earth and Environmental Science, 235. https://doi.org/10.1088/1755-1315/235/1/012062

Patriadi, H. B., Bakar, M. Z. A., \& Hamat, Z. (2015). Human security in local wisdom perspective: pesantren and its responsibility to protect people. Procedia Environmental Sciences, 28, 100-105. https://doi.org/10.1016/j.proenv.2015.07.015

Phongphit, S. and W. N. (2002). The Learning Process to Sustainable Development. Bangkok: Charoenwit.

Pornpimon, C., Wallapha, A., \& Prayuth, C. (2014). Strategy challenges the local wisdom applications sustainability in schools. Procedia-Social and Behavioral Sciences, 112, 626-634. https://doi.org/10.1016/j.sbspro.2014.01.1210

Rim-Rukeh, A., Irerhievwie, G., \& Agbozu, I. E. (2013). Traditional Beliefs And Conservation Of Natural Resources: Evidences From Selected Communities In Delta State, Nigeria. International Journal of Biodiversities and Conservation, 5(7), 426-432. https://doi.org/10.5897/IJBC2013.0576

Rohayu, R., \& Absori, A. (2019). Utilizing the Values of Local Wisdom: a Solution for Illegal Logging Conflict in Sumbawa Forest. International Journal of Social Sciences and Humanities, 3(1), 91-101.

Silaya, T. M., \& Siahaya, L. (2018). Local Wisdom Communities in Forest Resources Management in Mountainous of Manusela, North Seram. International Journal of Science and Research, 7(5), 1561-1565. https://doi.org/10.21275/ART20182447

Siswadi, Taruna, T., \& Purnaweni, H. (2011). Kearifan Lokal Dalam Melestarikan Mata Air (Studi Kasus Di Desa Purwogondo, Kecamatan Boja, Kabupaten Kendal). Jurnal Ilmu Lingkungan, 9(2), 63-68. https://doi.org/10.14710/jil.9.2.63-68

Suntoko, MPPS, P., Ruhailah. (2016). Sasi Role Of Tradition In The Management And Conservation Of Natural Resources As A Source of Human Life. International Journal of Education and Research, 4(6): 333-340.

Supriharyono. (2004). Effects Of Sand Mining On Coral Reefs in Riau Islands. Journal of Coastal Development, $7(2), 89-100$.

Syah, P. R. I. \& Hartuti, P. (2018). Land Use and River Degradation Impact of Sand and Gravel Mining, Proceedings of E3S Web Of Conferences, 31, 1-4.

Vitasurya, V. R. (2016). Local wisdom for sustainable development of rural tourism, case on Kalibiru and Lopati village, province of Daerah Istimewa Yogyakarta. Procedia-Social and Behavioral Sciences, 216, 97108. https://doi.org/10.1016/j.sbspro.2015.12.014

Widiastuti, M. M. D., \& Mote, N. (2018). Analisis Willingness to Accept (WTA ) terhadap Harga Pasir Pantai yang Terinternalisasi Biaya Eksternalitas di Kabupaten Merauke (Analysis Willingnes to accept ( WTA ) of Sand Beach with Internalization of Externality Price in Merauke Regency). Jurnal Agribisnis Perikanan, 11(2), 44-50. https://doi.org/10.29239/j.agrikan.11.2.44-50.

Widodo, J. (2012). Urban environment and human behaviour: learning from history and local wisdom. Procedia-Social and Behavioral Sciences, 42, 6-11. https://doi.org/10.1016/j.sbspro.2012.04.161

Hallatu, T. G. R., Wisadirana, D., Mu'adi, S., \& Chawa, A. F. (2021). Illegal sand mining and sar local wisdom: a case study in Merauke. International Journal of Social Sciences and Humanities, 5(1), 45-56.

https://doi.org/10.29332/ijssh.v5n1.827 


\section{Biography of Authors}

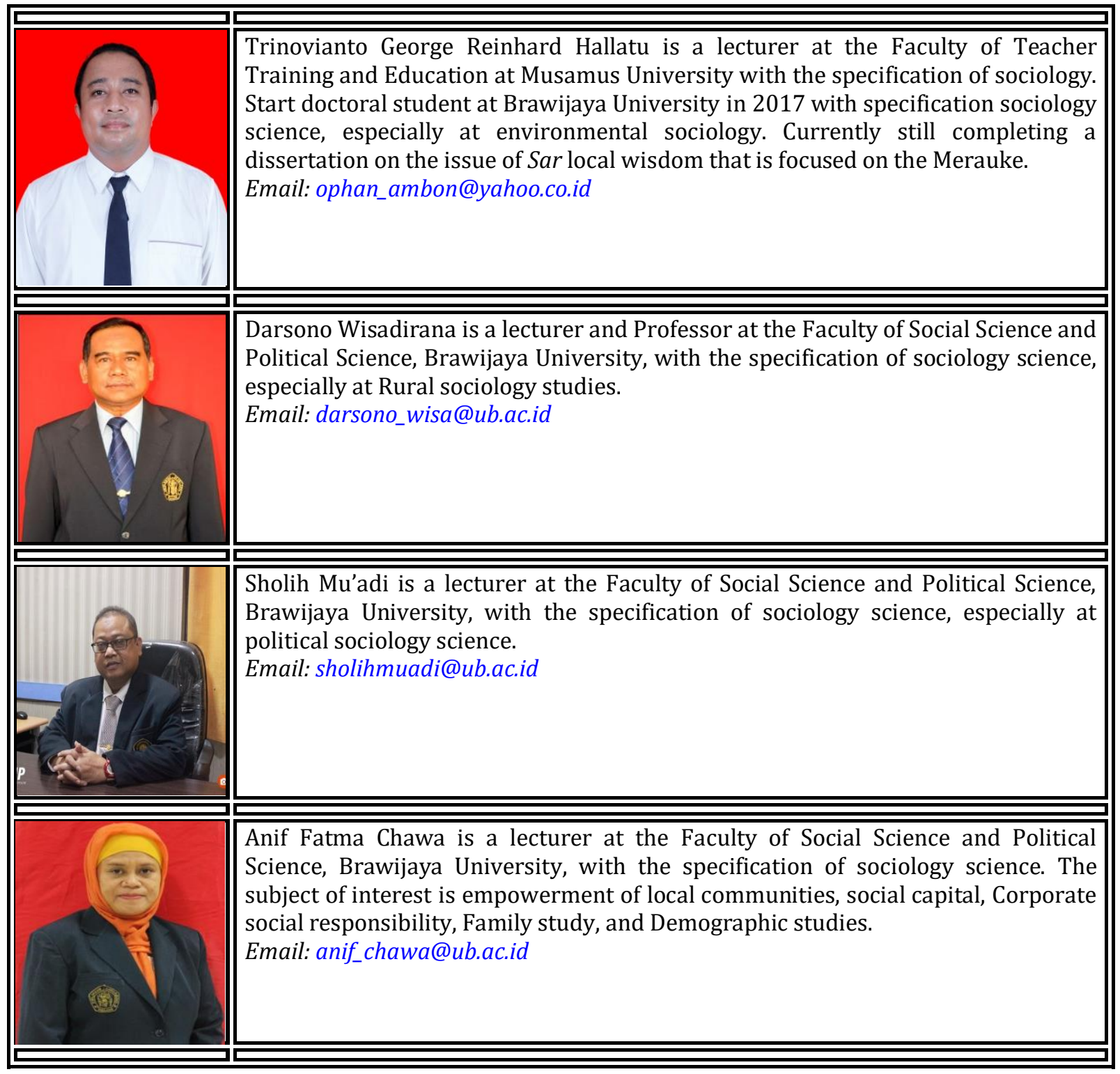

